\title{
A Survey of Dental Caries and Periodontal Disease Prevalence in the Students of Kyushu Dental College and School of Dental Hygiene
}

\author{
Hideo Miyazaki, Miyuki Itoh-Andoh, Yoshihisa Yamashita, \\ Toshiaki Saito, Akira Sogame, Ryuji Shirahama \\ and Tadamichi Takehara
}

Department of Preventive Dentistry (Chief: Prof. Tadamichi Takehara)

Kyushu Dental College, Kitakyushu, Japan

Received August 5, 1987

Key words: $D M F / C P I T N /$ College Students

\section{Introduction}

Surveys of dental diseases were performed on a portion of the students attending Kyushu Dental College and the School of Dental Hygiene, Kyushu Dental College, in 1968 1), $1972^{2}$ and $1974^{3)}$. The present survey was conducted on all students to compare the prevalence of dental diseases between the present and past (20 years ago) students. It was also conducted to determine the changes in the student's recognition of dental disease prevention, with the present college curriculum, by examining the condition or treatment needs of their dental diseases.

\section{Materials and Methods}

In May 1987, a survey was made of the dental caries and periodontal disease prevalence in 768 of $805(95.4 \%)$ students, (511 males and 257 females), from Kyushu Dental College (abbreviated to college students) and the School of Dental Hygiene, Kyushu Dental College (hygiene school students). The survey utilized the DMF index for permanent teeth, and the Community Periodontal Index of Treatment Needs (CPITN ${ }^{4)}$. Examinations were carried out in a college room, with sufficient illumination, provided by artificial light. Dental mirrors, explorers and WHO periodontal examination probes (Yamaura Seisakusho Ltd.) were used. The criteria used for the diagnosis of dental caries, were those recommended by the $\mathrm{WHO}^{5)}$. Decayed, filled and sound teeth were scored according to the WHO guidelines. Missing teeth were presumed to have been extracted. Seven examiners assessed the periodontal status according to the examination method of index teeth by Ainamo, et al. ${ }^{4}$ ) The data were analyzed using an NEC Personal Computer PC-9801/F2. 


\section{Results}

Table 1 shows the mean age of the subjects and the mean number of DMF teeth in the students according to the college year. The mean number of DMF teeth was 8.99 in the 1st-year students, and gradually increased with successive years, reaching 11.31 in the 6th-year students. The mean number of DMF teeth in the 1st- and 2nd-year hygiene school students was about two more than that in the 1st-year college students who were of similar age. For the students in each college year, the mean number of decayed and missing teeth due to dental caries was under 1.41. Most of the DMF teeth were filled. The percentage of decayed teeth, per DMF tooth, was $9.8 \%$ in the 1 styear students. The percentage increased with each successive year, and reached a maximum percentage $(14.0 \%)$ in the 3rd-year students. However, the percentage decreased from the 4 th- to 6 th-year students, and reached a minimum percentage $(3.2 \%)$ in the 6 th-year students.

Concerning the periodontal disease prevalence by age group, the data obtained from the $30^{-}$to 44 -year-old students, are shown in the tables together, as only a few subjects were examined.

Table 2 shows the percentage of students showing some signs of periodontal disease, according to age and sex, using the WHO guidelines (the rate of those giving the most severe symptomatic grade). In 18 - and 19 -year-old students, $90 \%$ of the males and $82 \%$ of the females showed some signs of periodontal diseases. Supra- or subgingival calculus (Code 2) was observed in $72-78 \%$ of the $18^{-}$to 29 -year-old students. Pathologic pockets 4 or $5 \mathrm{~mm}$ deep (Shallow pockets; Code 3) were observed in $6-8 \%$ of the 18 - to 29-year-old students, and pathologic pockets $6 \mathrm{~mm}$ or deeper (Deep pockets; Code 4)

Table 1 Mean age and mean number of DMF teeth in college students by year

\begin{tabular}{|c|c|c|c|c|c|c|}
\hline Year & $\mathbf{N}$ & Age & DMF & $\mathrm{D}$ & $\mathbf{M}$ & $F$ \\
\hline 1st & 120 & $\begin{array}{c}19.90 \\
(2.73)\end{array}$ & $\begin{array}{l}8.99 \\
4.88\end{array}$ & $\begin{array}{l}0.88 \\
(1.59\end{array}$ & $\left(\begin{array}{l}0.05 \\
0.21\end{array}\right)$ & $\begin{array}{l}8.06 \\
5.09)\end{array}$ \\
\hline 2nd & 100 & $\begin{array}{r}21.09 \\
(3.27)\end{array}$ & $\begin{array}{l}9.18 \\
(4.65)\end{array}$ & $\left(\begin{array}{l}1.12 \\
1.79\end{array}\right)$ & $\begin{array}{l}0.08 \\
(0.31)\end{array}$ & $\begin{array}{l}7.98 \\
(4.47)\end{array}$ \\
\hline $3 \mathrm{rd}$ & 117 & $\begin{array}{c}21.68 \\
(2.42)\end{array}$ & $\begin{array}{c}10.10 \\
(5.15)\end{array}$ & $\left.\begin{array}{l}1.41 \\
(1.89\end{array}\right)$ & $\begin{array}{l}0.19 \\
0.56\end{array}$ & $\begin{array}{l}8.50 \\
(5.16)\end{array}$ \\
\hline 4 th & 117 & $\begin{array}{c}23.21 \\
(3.05)\end{array}$ & $\begin{array}{c}10.23 \\
(4.84)\end{array}$ & $\begin{array}{l}0.98 \\
(1.59)\end{array}$ & $\left(\begin{array}{l}0.31 \\
0.79\end{array}\right)$ & $\begin{array}{l}8.94 \\
(4.66)\end{array}$ \\
\hline 5 th & 128 & $\begin{array}{c}23.80 \\
(2.48)\end{array}$ & $\begin{array}{c}11.01 \\
(5.06)\end{array}$ & $\begin{array}{l}0.97 \\
1.85\end{array}$ & $\begin{array}{c}0.53 \\
(1.32)\end{array}$ & $\begin{array}{c}9.51 \\
(5.12)\end{array}$ \\
\hline $6 \mathrm{th}$ & 108 & $\begin{array}{r}24.49 \\
(2.73)\end{array}$ & $\begin{array}{c}11.31 \\
(5.53)\end{array}$ & $\begin{array}{l}0.36 \\
0.78)\end{array}$ & $\begin{array}{l}0.36 \\
(0.78)\end{array}$ & $\begin{array}{c}10.59 \\
(5.45)\end{array}$ \\
\hline 1st $\quad(\mathrm{DH})$ & 40 & $\begin{array}{r}18.33 \\
(0.47)\end{array}$ & $\begin{array}{c}10.71 \\
(4.51)\end{array}$ & $\begin{array}{l}0.58 \\
(1.32)\end{array}$ & $\begin{array}{l}0.03 \\
0.16)\end{array}$ & $\begin{array}{r}10.10 \\
(4.37)\end{array}$ \\
\hline 2nd (DH) & 38 & $\begin{array}{r}19.24 \\
(0.59)\end{array}$ & $\begin{array}{c}11.68 \\
(5.37)\end{array}$ & $\begin{array}{l}0.47 \\
1.11)\end{array}$ & $\begin{array}{l}0.18 \\
(0.69)\end{array}$ & $\begin{array}{c}11.03 \\
(5.27)\end{array}$ \\
\hline
\end{tabular}


Table 2 Percentage of students showing signs of periodontal disease by age group and $\operatorname{sex}(\mathrm{N}=768)$

\begin{tabular}{lcrrrrrr}
\hline & Age & N & $\begin{array}{l}\text { No } \\
\text { periodontal } \\
\text { disease }\end{array}$ & $\begin{array}{l}\text { Bleeding } \\
\text { only }\end{array}$ & Calculus & $\begin{array}{l}\text { Shallow } \\
\text { pockets }\end{array}$ & $\begin{array}{l}\text { Deep } \\
\text { pockets }\end{array}$ \\
\hline \multirow{3}{*}{ Males } & $18-19$ & 68 & 10 & 10 & 72 & 7 & 0 \\
& $20-29$ & 415 & 7 & 5 & 78 & 8 & 1 \\
& $30-44$ & 28 & 4 & 0 & 79 & 14 & 4 \\
\hline \multirow{5}{*}{ Females } & $18-19$ & 108 & 18 & 6 & 70 & 6 & 0 \\
& $20-29$ & 144 & 13 & 6 & 76 & 6 & 0 \\
& $30-44$ & 5 & 20 & 0 & 60 & 0 & 20 \\
\hline \multirow{4}{*}{ Total } & $18-19$ & 176 & 15 & 8 & 71 & 6 & 0 \\
& $20-29$ & 559 & 8 & 5 & 78 & 8 & 1 \\
& $30-44$ & 33 & 6 & 0 & 76 & 12 & 6 \\
\hline
\end{tabular}

Table 3 Percentage of students showing signs of periodontal disease by year $(\mathbf{N}=768)$

\begin{tabular}{lcccccc}
\hline \hline Year & N & $\begin{array}{l}\text { No } \\
\text { periodontal } \\
\text { disease }\end{array}$ & $\begin{array}{l}\text { Bleeding } \\
\text { only }\end{array}$ & Calculus & $\begin{array}{l}\text { Shallow } \\
\text { pockets }\end{array}$ & $\begin{array}{l}\text { Deep } \\
\text { pockets }\end{array}$ \\
\hline 1st & 120 & 6 & 4 & 81 & 8 & 1 \\
2nd & 100 & 7 & 9 & 79 & 5 & 0 \\
3rd & 117 & 4 & 5 & 77 & 12 & 2 \\
4th & 117 & 8 & 1 & 82 & 9 & 0 \\
5th & 128 & 8 & 9 & 74 & 9 & 1 \\
6th & 108 & 15 & 7 & 71 & 5 & 2 \\
1st (DH) & 40 & 20 & 3 & 73 & 5 & 0 \\
2nd (DH) & 38 & 34 & 8 & 58 & 0 & 0 \\
\hline
\end{tabular}

DH : School of Dental Hygiene

were observed in $1 \%$ of the 20 - to 29 -year-old males. The percentage of students affected increased with age, and tended to be higher in the males than in the females.

The percentage of students having no periodontal disease (Code 0 ), including gingival bleeding after gentle probing (Code 1), supra- or subgingival calculus and pathologic pockets, was similar between the 1st- and 5th-year college students. However, the percentage of students showing a healthy periodontal status was higher in the 6th-year college students and the hygiene school students than in the 1st- to 5th-year college students (Table 3 ).

The mean number of sextants affected was similar among age groups; however, more males than females were affected (Table 4). The mean number of sextants affected was similar between the 1st- and 4th-year college students. In the 6th-year college students and the 1st- and 2nd-year hygiene school students, the number of sextants affected was less than in the 1 st- to 4 th-year college students (Table 5). 
Table 4 Mean number of sextants affected by age group and sex

\begin{tabular}{lcrcccc}
\hline & Age & $\mathrm{N}$ & $\begin{array}{l}\text { Bleeding } \\
\text { only }\end{array}$ & Calculus & $\begin{array}{l}\text { Shallow } \\
\text { pockets }\end{array}$ & $\begin{array}{l}\text { Deep } \\
\text { pockets }\end{array}$ \\
\hline \multirow{3}{*}{ Males } & $18-19$ & 68 & 3.4 & 2.3 & 0.1 & 0.0 \\
& $20-29$ & 415 & 3.3 & 2.5 & 0.1 & 0.0 \\
& $30-44$ & 28 & 3.8 & 2.7 & 0.3 & 0.1 \\
\hline \multirow{3}{*}{ Females } & $18-19$ & 108 & 2.4 & 1.7 & 0.1 & 0.0 \\
& $20-29$ & 144 & 2.7 & 2.0 & 0.1 & 0.0 \\
& $30-44$ & 5 & 3.2 & 2.6 & 0.2 & 0.2 \\
\multirow{3}{*}{ Total } & $18-19$ & 176 & 2.8 & 2.0 & 0.1 & 0.0 \\
& $20-29$ & 559 & 3.2 & 2.4 & 0.1 & 0.0 \\
& $30-44$ & 33 & 3.7 & 2.7 & 0.3 & 0.1 \\
\hline
\end{tabular}

Table 5 Mean number of sextants affected by year

\begin{tabular}{lccccc}
\hline Year & N & $\begin{array}{c}\text { Bleeding } \\
\text { only }\end{array}$ & Calculus & $\begin{array}{l}\text { Shallow } \\
\text { pockets }\end{array}$ & $\begin{array}{l}\text { Deep } \\
\text { pockets }\end{array}$ \\
\hline 1st & 120 & 3.4 & 2.5 & 0.1 & 0.0 \\
2nd & 100 & 3.4 & 2.2 & 0.1 & 0.0 \\
3rd & 117 & 3.8 & 2.7 & 0.3 & 0.0 \\
4th & 117 & 3.4 & 2.7 & 0.1 & 0.0 \\
5th & 128 & 2.8 & 2.3 & 0.1 & 0.0 \\
6th & 108 & 2.5 & 1.8 & 0.1 & 0.0 \\
1st (DH) & 40 & 2.3 & 1.8 & 0.1 & 0.0 \\
2nd (DH) & 38 & 1.5 & 1.2 & 0.0 & 0.0 \\
\hline
\end{tabular}

DH : School of Dental Hygiene

Table 6 Service requirements by age group and sex (\%)

\begin{tabular}{lcrccc}
\hline & Age & $\mathrm{N}$ & $\begin{array}{l}\text { Hygiene } \\
\text { instruction }\end{array}$ & Prophylaxis & $\begin{array}{c}\text { Complex } \\
\text { treatment }\end{array}$ \\
\hline \multirow{4}{*}{ Males } & $18-19$ & 68 & 90 & $79(2)$ & $0(0)$ \\
& $20-29$ & 415 & 93 & $88(3)$ & $1(0)$ \\
& $30-44$ & 28 & 96 & $96(3)$ & $4(0)$ \\
\hline \multirow{5}{*}{ Females } & $18-19$ & 108 & 82 & $76(2)$ & $0(0)$ \\
& $20-29$ & 144 & 88 & $82(2)$ & $0(0)$ \\
& $30-44$ & 5 & 80 & $80(3)$ & $20(0)$ \\
\hline \multirow{5}{*}{ Total } & $18-19$ & 176 & 85 & $77(2)$ & $0(0)$ \\
& $20-29$ & 559 & 92 & $86(2)$ & $1(0)$ \\
& $30-44$ & 33 & 94 & $94(3)$ & $6(0)$ \\
\hline
\end{tabular}

( ) : Mean number of sextants affected 
Table 7 Service requirements by year $(\%)$

\begin{tabular}{lcccc}
\hline Year & $\mathbf{N}$ & $\begin{array}{l}\text { Hygiene } \\
\text { instruction }\end{array}$ & Prophylaxis & $\begin{array}{c}\text { Complex } \\
\text { treatment }\end{array}$ \\
\hline 1st & 120 & 94 & $90(3)$ & $1(0)$ \\
2nd & 100 & 93 & $84(2)$ & $0(0)$ \\
3rd & 117 & 96 & $91(3)$ & $2(0)$ \\
4th & 117 & 92 & $91(3)$ & $0(0)$ \\
5th & 128 & 92 & $84(2)$ & $1(0)$ \\
6th & 108 & 85 & $78(2)$ & $2(0)$ \\
1st (DH) & 40 & 80 & $78(2)$ & $0(0)$ \\
2nd (DH) & 38 & 66 & $58(1)$ & $0(0)$ \\
\hline
\end{tabular}

DH : School of Dental Hygiene

( ) : Mean number of sextants affected

Eighty-five percent of the $18^{-}$and 19 -year-old students, and $92 \%$ of the $20^{-}$to 29 year-old students, were diagnosed as requiring oral hygiene instruction. Seventy-seven percent of the 18- and 19-year-old students and $86 \%$ of the 20 - to 29-year-old students were diagnosed as requiring oral prophylaxis (Table 6). The number of 2nd-year hygiene school students, requiring periodontal services was lower than that in any other year. A small percentage of college students were diagnosed as requiring complex treatment. Over $90 \%$ of the students between the 1 st- and 5 th-year were diagnosed as requiring oral hygiene instruction (Table 7 ).

\section{Discussion}

In the 1967 survey, the mean number of DMF teeth in the college students (21.8 years of age) and the hygiene school students (18.7 years of age) was 5.05 and 6.20, respectively ${ }^{1)}$. In 1972 , this figure increased to 8.23 in the college students (23.0 years of age ${ }^{2)}$, and in 1974, it increased to 10.08 in the hygiene school students (19.0 years of age ${ }^{3)}$. In the present study, the mean number of DMF teeth further increased to twice that observed 20 years ago. Such an increase in the prevalence of dental caries in college students reflects the changes in the general Japanese population. The mean number of DMF teeth in the college students was one to two less than that in the general Japanese population, described in the 1981 report of the survey of dental disea$\operatorname{ses}^{6)}$. They cannot be compared directly, however, as there was a time lag of six years. Further, the percentage of filled teeth per DMF tooth was higher in the college students than in the general Japanese population ${ }^{6)}$. These results indicate that the level of recognition of dental caries is higher among the college students. In the assessment of the percentage of decayed (untreated) teeth per DMF tooth, by college year, a gradual increase, from $9.8 \%$ in the 1 st-year to $14.0 \%$ in the $3 \mathrm{rd}$-year, was noted. However, it was depressed in the 4 th-year and reached it's lowest value of $3.2 \%$ in the 6 th-year (these data are not shown in the table). It is suspected that these results may 
be closely related to the curriculums for lectures and practices, in the dental college.

On the other hand, the periodontal status was not impressive, and a similar condition existed between the college students over 20 years of age and those ${ }^{7 \sim 12}$ of the same age who were not related to dentistry. However, female students under 20 years of age (hygiene school students) maintained a better periodontal status than the general population $^{7 \sim 12}$ of the same age. The periodontal disease prevalence by college year shows that the 6th-year students and hygiene school students maintained much better periodontal health than college students in other years. These results may reflect the motivation for periodontal disease prevention in hygiene school students. The results may also be explained by the younger age of the hygiene students and the fact that they receive lectures and training for dental disease prevention in their 1st year. This can also explain the results of the 6th-year college students. Briefly, the depressed prevalence of periodontal diseases in this group may be ascribable to the practice of tooth brushing for three weeks in the 5th-year, and the oral hygiene instruction for out-patients of the college hospital and the scaling practice among students in the 5thand 6 th-year.

All students who want to be dentists should have good oral health. As they move up to the professional course (3rd-year) and begin to receive lectures on dentistry, they become much more interested in dental diseases. As a result, the percentage of filled teeth, per decayed tooth which can be diagnosed easily by themselves, will be elevated in the 4th-year. However, students receiving lectures on periodontology or preventive dentistry are not able to determine the presence or degree of disease in their periodontal status through only their knowledge. Even if they are able to consider it, they are not able to take appropriate countermeasures. For these reasons, the recovery of periodontal health may be delayed for two years (in the 6th-year) than treatment of decayed teeth.

As shown by the results of the survey on the hygiene school students, periodontal health can be easily maintained by learning about preventive dentistry, and mutual scaling practice (their scaling technique is not yet skilled) for one year. The extremely high prevalence of periodontal diseases in the 1st- to 5th-year college students presents a problem in the future planning of curriculums for the dental college. It is necessary to take measures, including the incorporation of lectures on preventive dentistry in lower college years and the introduction of scaling practice, in order that dental students will be able to manage their own dental health.

\section{Summary}

In May 1987, a survey was carried out to determine the prevalence of dental caries and periodontal disease in 768 of the $805(95.4 \%)$ students of Kyushu Dental College and the School of Dental Hygiene. The aim of this survey was to grasp the changes in dental diseases between college students in 1967 and those in 1987, and to determine their recognition for the prevention of dental diseases. The mean number of DMF teeth 
and the percentage of decayed teeth per DMF tooth were lower in the students than in the general Japanese population. The mean number of DMF teeth, however, was twice as many in the present students as in the students of 20 years ago. The mean number of DMF teeth was 8.99 in the 1st-year students and gradually increased with the year, reaching 11.31 in the 6 th-year students. The percentage of decayed teeth per DMF tooth increased with the year and reached a maximum percentage $(14.0 \%)$ in the 3rdyear students. Conversely, the percentage decreased with the year from the 4 th- to 6 th-year, and reached a minimum percentage $(3.2 \%)$ in the 6 th-year students. While the percentage of students showing some signs of periodontal disease was similar between the 1st-and 5th-year students, the percentage was also similar between these groups and the other populations. However, the 6th-year students of the college and the students of the school of dental hygiene had healthy periodontal status. These findings revealed that the college students' recognition for periodontal disease prevention differed from dental caries prevention and was lacking until they were promoted to the 6th-year.

\section{References}

1) Ninomiya, F., Saeki, E., Abe, S., Fukuhara, T., Hashimoto, K. and Miyagawa, Y.: An investigation result on the DMFT in the students of Kyushu Dental College and two other universities. J. Kyushu Dent. Soc. $22: 114-118,1968$, (in Japanese).

2) Saeki, E. and Matsumoto, H. : An oral healthy investigation on the tooth, gingiva and its environment (The first report). J. Kyushu Dent. Soc. $26: 165-175$, 1973, (in Japanese) .

3 ) Saeki, E. and Matsumoto, H. : An oral healthy investigation on the tooth, gingiva and its environment (The second report). J. Kyushu Dent. Soc. 29:384-389, 1975, (in Japanese).

4 ) Ainamo, J., Barmes, D., Beagrie, G., Cutress, T., Martin, J. and Sardo-Infirri, J. : Development of the World Health Organization (WHO) Community Periodontal Index of Treatment Needs (CPITN). Int. Dent. J. 32:281-291, 1982.

5 ) World Health Organization : Oral health survey - Basic methods. Geneva : W HO, 1977.

6 ) Division of Dental Health Medical Affaires Bureau Ministry of Health and Welfare : Report on the survey of dental diseases (1981), Kokuhokenkyokai, Tokyo, 1983, 124-126, (in Japanese).

7) Kitahara, M., Takano, K., Horiuchi, K., Matsusaka, K. and Mukai, S. : A survey on periodontal disease in Fujisawa with CPITN (WHO). J. Dent. Hlth 34:576-583, 1984, (in Japanese).

8 ) Suzuki, Y., Kouyama, Y., Maita, E. and Horiuchi, H. : A survey of periodontal diseases using Community Periodontal Index of Treatment Needs (CPITN) suggested by the WHO. J. Japan. Ass. Periodont. 27:473-481, 1985, (in Japanese).

9) Hagiwara, S., Honma, S., Asai, H., Konno, T., Ohshima, M., Izumizawa, K., Noguchi, T. and Ishikawa, I. : Epidemiological survey on periodontal disease in the employees of two banks with CPITN (Community Periodontal Index of Treatment Needs) - The second report-. J. Japan. Ass. Periodont. 27:635-642, 1985, (in Japanese).

10) Takehara, T., Miyazaki, H., Andoh, A., Hanada, N., Itoh, M., Nakayama, K., Saitoh, T., Sogame, A. and Saeki, E. : A survey of periodontal disease in new patients at 
Kyushu Dental College Hospital. J. Kyushu Dent. Soc. 40:427-430, 1986, (in Japanese).

11) Kani, M., Iino, S., Kani, T., Isozaki, A., Tsutaho, T., Hirose, A., Okuno, M., Kato, H., Ikawa, E., Kuwahara, S., Kajita, H. and Okuda, M. : The CPITN survey on industrial workers - Relationship between CPITN and VPI, periodontal subjective symptoms-. J. Dent. Hlth $36: 296-305,1986$, (in Japanese).

12) Miyazaki, H., Hanada, N., Itoh-Andoh, M., Sogame, A., Sakuma, M. and Takehara, T. : Periodontal treatment needs of industrial workers. J. Dent. Hlth $37: 150-154,1987$. 


\title{
九州歯科大学および附属歯科衛生学院学生の 歯科疾 患実態調 査
}

\author{
九州歯科大学口腔衛生学講座（主任：竹原直道教授） \\ 宮崎 秀夫・安東 美幸・山下 喜久・斎藤 敏昭 \\ 十亀輝 - 白浜立二. 竹原 直道
}

1987年 5 月に，九州霜科大学および附属歯科衛生学院 学生 768 名（受診率 $95 \%$ ）を対象として，触蝕と雨周疾 患の実態調查を行なった。乙の調查の目的は，20年前の 本学学生と比較して現在の学生の菊科疾患有病に, ぞの ような変動があるかを知るととと，現学生の菌科疾患の 処置状況，或いは処置の必要性を通して，歯科疾患予防 に対する彼らの認識を推察し, 歯科専門講義のカリキュ ラムによる彼らの認識の変化を把握するととであった．

敨蝕有病を DMF 歯数でみると, 進 1 の 9.0 本から学 年の上昇に伴って増加し, 学 4 では11.3本であった。衛 生学院生は同年代である進 1 に比べて約 2 本多かった.

これらの值を20年前の本学学生の報告值と比較するとほ ほ 2 倍に増加していた。しかしながら，ての増加傾向は 日本人全般の唃蝕有病状態の変貎が本学学生に反映して いる結果にすぎず，日本全国レベルからすると，本学学 生の DMF 歯数は若干少ない状海にある.これが処置 霜率, 或いは未処置率でみると，本学学生は極めて優れ た結果を示しており，雷蝕に関する限りでは，本学学生 の認識の高さを伺うことができる．表には示してない が，離蝕の未処置柬率を学年別にみると，進 1 の $9.8 \%$ から高学年になるほど高率化し，学1で14.0\%とピーク に達した，学 2 以降ではこの率は次第に低下し，学 4 で 最低の $3.2 \%$ とった。この結果は本学の歯科専門講義, 実習のカリキュラムと極めて密接な関係が示唆されてい るように思える。

一方，歯周疾患有病では，歯周疛患の徵候がみられな い者 (Code 0), 歯肉出血のある者 (Code 1), 歯石沈 着のみられる者 (Code 2), $4 \mathrm{~mm}$ 以上の雨周ポケット を有する者 (Code 3, Code 4) ともに, 進 1 加ら学 3 まで大差はなかった，それに対して，学 4 と衛生学院生
は他の学年に比べて健康な蒌周組織を有する者の割合が 高かった. 有病部位数でみても同様の傾向が示された. また，乙れらの調查結果は，霜科分野と無関係な同年代 の者と比較して, 進 1 から学 3 までの学生は菌周組織が 健康であるとは言い難いことを示していた。しかしなが ら, 衛生学院生と学 4 の学生は, 同世代の一般市民上り 高い健康レベルにあった。衛生学院では歯科族患予防に 関する講義や実習がメインであるから，学院生は年齿令が 若いのに加えて, 茵周疾患予防に対するモチべーション がなされている結果が現われているのであろう．学4の 学生にも同様のことが言える.つまり, 学 3 の口腔衛生 実習で， 3 週にわたってブラッシング実習を行なったて と, 学 3 の終わり頃からの登院で, 患者に対する口腔衛 生指導に接しだしたととなどが蒾周組織の健康回復につ ながってきたものと思われる。

少なくとも，本学学生は自分の口腔内の健康を望ま奴 者はいないはずであるし, 学部に進学し, 歯科学の講義 が始まると一層菌科疾患隹対する関心は高まってくるも のである、その結果，自己診断が行ないやすい触蝕で は, その処置率は学 2 亿進級した頃から高くなってくる のであろう。しかしながら，来周疾患に関しては登院す るまでその回復はみられない，講義を受けた尃門知識だ けでは, 自分の蒾周の健康状態は把握できないのか, 或 いは，自覚はあってもその対処の具体的方法がわからな いのかも知れない，衛生学院生の調査結果に示されてい るように，1年間の予防歯科の学習と相互除石実習一完 全な除石を行なえるだけの実力はまだない一のみで, 歯 周組織の健康回復・保持は容易にはかれるのである。 そ の点を考えると, 学 3 までの菌周疾患の極めて高い有病 状沉は, 今後の大学の課題として問題を提起している。 